\title{
Le petit paradis des blessés
}

\section{Introduction: the little paradise}

The majority of British and North American women who cared for the war's wounded were posted to official army medical units. Yet, volunteer hospitals played a significant role in the military medical efforts of all allied nations. ' 'L'Hôpital Chirurgical Mobile No. 1' was one of the most unusual military hospitals of modern times. The unit - one of the closest to the front lines near Ypres - was donated to the French Service de Santé by American millionaire philanthropist Mary Borden Turner, ${ }^{2}$ an enigmatic woman, known by those who read the British Journal of Nursing as 'Mrs Turner'; by her own nurses as 'La Directrice'; and, later, by all, as 'Lady Spears'. The name she used as author of her many books was simply her maiden name: 'Mary Borden. ${ }^{3}$ Her hospital, which came to be known amongst the French as 'le petit paradis des blessés', was the result of a remarkable feat of persuasion: she met directly with General Joffre in the spring of 1915 and convinced him that, even though she had worked as a volunteer nurse for only a few months and had no previous nursing training or experience, she was capable of creating and directing a front-line hospital. She opened L'Hôpital Chirurgical Mobile No. 1 - a hutted encampment of about 160 beds - in July 1915, in the small Belgian town of Rousbrugge. ${ }^{4}$ Throughout the war, she clung resolutely to the right to direct her hospital, even after such independent, voluntary establishments had been effectively outlawed by the allied military medical services. She also insisted on retaining the right to appoint all of her 
unit's nurses, many of whom were fully trained British, American, Australian, and Canadian professionals. The hospital's doctors and orderlies operated under the auspices of the French military medical services, but its day-to-day running remained in Borden's own hands.

During the Somme campaign, Borden established a new, much larger hospital at Bray-sur-Somme, ${ }^{5}$ but L'Hôpital Chirurgical Mobile No. 1 remained in Belgium, moving two or three times when it came under heavy shelling. ${ }^{6}$ In April 1917, Borden established a third hospital behind the Chemin des Dames, to support the Nivelle offensive. ${ }^{7}$

\section{Narratives of L'Hôpital Chirurgical Mobile No. 1}

The staffing of L'Hôpital Chirurgical Mobile No. 1 was made possible, in part, by the efforts of Grace Ellison, founder of the 'French Flag Nursing Corps' (FFNC). ${ }^{8}$ Ellison had obtained some of her schooling in France, and felt, by her own account, a 'deep love' for the country. Just after the Battle of the Marne she travelled there to offer her services as a 'very willing but amateur nurse.' She quickly realised that France had very few fully qualified professional nurses. Although some care was offered by highly trained and experienced nuns and a small cadre of professional nurses, most was in the hands of untrained orderlies and 'volunteer-ladies'. The work of the latter was coordinated by the French Red Cross, which was a more significant force than its sister-organization across the English Channel. ${ }^{10}$ Some French volunteer nurses had passed a series of technical examinations and held the title 'infirmière-major', but most, in the words of Ellison, 'had as diplomas their good intentions only. ${ }^{11}$

Ellison's response to the shortage of fully trained nurses in France was to offer the French minister of war 'a little army of fully trained British nurses, ${ }^{12}$ who might be deployed in French military hospitals to fill the gaps in the existing provision. This and other opportunities for British nurses to travel to France and work close to the front lines coincided with a failure of the British military medical services to make full use of their professional skills and knowledge. Anne Summers has pointed out that, in the decades prior to the First World War, the QAIMNS - whilst fully recognised as an elite nursing corps - had remained small, with the bulk of potential military nurses forming its 'Reserve' or belonging to the Territorial Force Nursing 
Service. ${ }^{13}$ Although these existing services were rapidly mobilised in August 1914, the British army was slow to make full use of the large numbers of other fully trained nurses who came forward to offer their services to the war effort. In fact, the tendency for the British army to allow untrained volunteers of high social status to establish their own hospitals in Belgium and northern France angered members of the nursing profession, and led many to offer their services to organisations such as the FFNC. ${ }^{14}$

Keen to be close to the front lines, to make use of their skills, and to be part of a great enterprise that they believed would soon be over, trained British nurses travelled to France and Belgium with a number of organisations operating under the auspices either of the Red Cross or of overseas military medical services. 'A curious crowd they were', commented Ellison, 'all suffering from war fever. ${ }^{15}$ Many of those who applied to the FFNC did not hold certificates of training, and Ellison sought the services of campaigner for state registration Ethel Gordon Fenwick to assist in the selection of only the most fully trained. ${ }^{16}$ No volunteer nurses were admitted to the ranks of the FFNC. Ellison remarked with pride that 'they were all highly qualified women with the real pioneer spirit. ${ }^{17}$ The FFNC supplied more than half the nurses to L'Hôpital Chirurgical Mobile No $1,{ }^{18}$ the remainder being carefully selected from the ranks of those French nurses who had some form of recognised training. Their work was supported by French male orderlies.

Much has been written about L'Hôpital Chirurgical Mobile No. 1, most of it fragmentary and vague. ${ }^{19}$ Much can be unearthed by the diligent researcher, yet, even when carefully pieced together, the fragments provide only a half-formed image, full of lacunae, half-truths, and highly interpreted narratives. The historical record, although fairly voluminous, thus leaves the frustrated researcher with an insoluble puzzle. At least three published memoirs of women's wartime nursing experiences are reminiscences of L'Hôpital Chirurgical Mobile No. 1, and a fourth text appears to be a disguised account of the same hospital, in which names and details have been deliberately changed.

Mary Borden's The Forbidden Zone offers a series of vivid narratives. ${ }^{20}$ Highly allegorical and infused with its author's powerful sense of spirituality, Borden's text offers the reader 'fragments of a great 


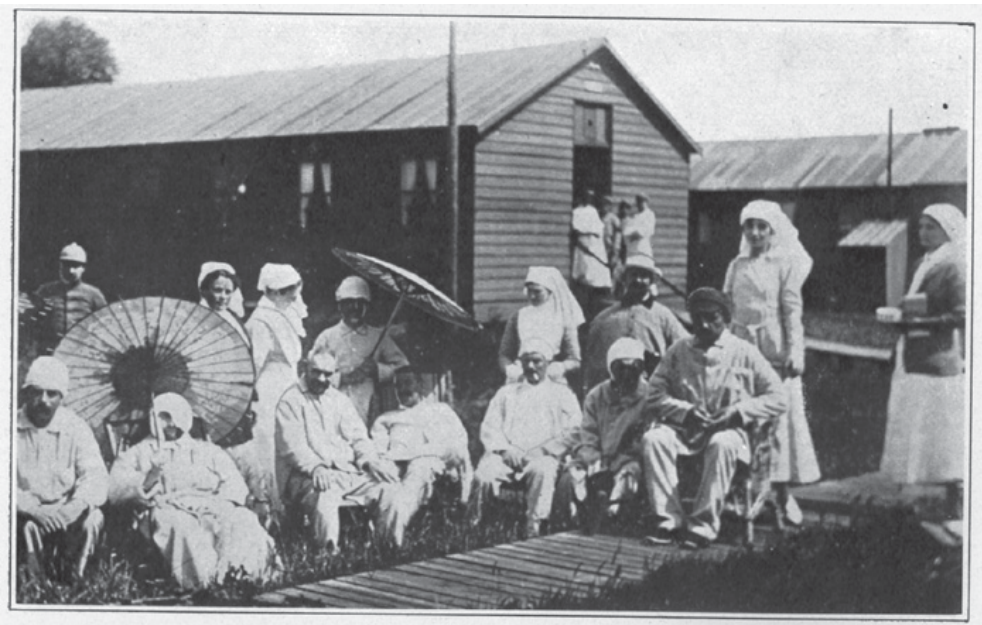

Figure 2 L'Hôpital Chirurgical Mobile No. 1

confusion. ${ }^{21}$ Written in a very similar style and yet with an entirely different tone, Ellen La Motte's The Backwash of War is shocking in its clarity and simplicity, horrifyingly successful in penetrating the reader's consciousness with its author's dark and disturbing vision of the war. ${ }^{22}$ Totally different from either of these is the writing of Canadian nurse Agnes Warner, who became Borden's 'Head Nurse' at Rousbrugge, and continued to direct the nursing care there following Borden's departure for Bray-sur-Somme in September 1916. Her letters home to her mother and sisters, published in New Brunswick without her knowledge as My Beloved Poilus, offer a homely and sympathetic perspective on the heroism of the hospital's French patients patients about whom Borden is pitying and La Motte scathing. ${ }^{23}$

A fourth text, although it never states which hospital it relates to, appears to be an account of L'Hôpital Chirurgical Mobile No. 1. A Green Tent in Flanders, authored by American volunteer nurse Maud Mortimer, describes a field hospital located in Belgium, donated to the French by its American 'Directress', who is an 'artist'. A number of vivid and colourful characters work at this hospital, among whom are a cynical nurse writer collecting material for a book, and a deeply compassionate and highly experienced Canadian nurse. ${ }^{24}$ 
One of the most intriguing images in these texts is the metaphor of the First World War as a vast sea, from which the wounded are washed up. Mary Borden's patients are 'lost men, wrecked men, survivors from that other world that was here before the flood passed this way, washed up against the shore of this world again by the great backwash. ${ }^{25}$ For Maud Mortimer, the waves of the war's ocean crash against a shore close to the hospital, and the patients are the 'spindrift of [a] shattered endeavour. ${ }^{26}$ For both writers, the war is filled with heroic effort. La Motte too conveys a watery metaphor; but hers carries a totally different meaning. In her introduction, she writes that: 'There are many little lives foaming up in the backwash. They are loosened by the sweeping current, and float to the surface, detached from their environment, and one glimpses them, weak, hideous, repellent. ${ }^{27}$ For La Motte, the sea of war is a turgid and relentless one, and the patients in the field hospital are the tiny, helpless, and essentially ugly life-forms that are disturbed by its movement.

In this chapter, the writings of Borden and Warner will be examined closely. Each was a significant figure within the hospital: Borden was its 'Directrice', Warner her 'Head Nurse'. But where Borden wore her authority with an air of glamour, Warner cloaked her more authentic clinical and professional leadership in a homely and dutiful demeanour.

\section{Mary Borden's Forbidden Zone}

In one sense, Mary Borden could be said to have been a chameleon. Changing not only her appearance, clothing, and manner, but apparently her entire personality, to fit into a range of backgrounds, she excelled as society hostess, successful novelist, and 'Directrice' of a French field hospital. Yet, this capacity for moulding her talents did not mean that, chameleon-like, she blended into the background. In her own writings, she refers to a French First World War nurse (possibly reflecting on her own appearance) as a 'white peacock', and it was, perhaps, her capacity for standing out from a crowd, exciting attention, and forming a striking impression on the mind that was her strongest characteristic. Born into a wealthy Chicago family, Borden enjoyed an expensive boarding-school education; married first a 
missionary and then a British staff officer; and moved in literary circles, enjoying relationships with members of the intelligentsia, such as Ford Madox Ford and Percy Wyndham Lewis. The extraordinary qualities of her writing owe much to her range of experiences and acquaintances. ${ }^{28}$

Born on 15 May 1886, Borden was one of four surviving siblings, and spent much of her time accompanying her brothers on expeditions, fishing trips, and games with other boys. Although something of a tomboy, she was also said to have been feminine in appearance and behaviour, and was reputed to have been a 'stylish and original dresser. ${ }^{29}$ The family home was a large house in a fashionable area by the shore of Lake Michigan. Her mother was devoutly Christian, and underwent an 'evangelical' conversion in the 1890s - an event that had a profound influence on the entire Borden household. ${ }^{30}$ Borden's education, first at Rye Seminary on Long Island and then at the prestigious Vassar College, nurtured her desire to be a writer and offered her both the classical education and the training in self-possession and independence of mind that would support her work. ${ }^{31}$

On her father's death in 1906, she inherited a share of his fortune. When she graduated from Vassar in 1907, she was persuaded by her mother to use some of her wealth to travel the world, visiting Christian mission stations. In Lahore she met Douglas Turner, the man who would become her first husband. Engaged to him within a week of their first meeting, she appears to have had doubts about the relationship, but married him in Lausanne, on 28 August $1908 .^{32}$ Moving to London in 1913, Borden began to publish novels under the pseudonym Bridget Maclagan, and became closely involved in the suffragette movement - even to the point of being arrested in the autumn of that year for throwing a stone at a window of the Treasury building in Whitehall. ${ }^{33}$

Borden's life in London consisted of lavish parties and the writing of novels about her experience in India. These pre-war novels set the trend for her writing, which always closely mirrored her own experiences. It was said that she was 'using her inheritance to buy her way into the London literary scene', and that her parties and soirées were among the most lavish and entertaining in the capital. ${ }^{34}$

When Britain entered the First World War in August 1914, Borden was pregnant with her third daughter, Mary. She volunteered her 
services to the London Committee of the French Red Cross, and, soon after Mary's birth, travelled to Malo-les-Bains near Dunkirk to nurse typhoid patients. Her first posting was to a makeshift hospital in a converted casino and she was appalled by its lack of equipment and trained staff. She herself had undergone no formal nurse training at all and was obliged to learn from better experienced British colleagues and from her own mistakes. ${ }^{35}$ As she gained experience, she became openly critical of the poor care received by the casino's patients. Eventually, she decided to write to General Joseph Joffre, Commander in Chief of the French forces, offering to fund, staff, and run her own field hospital. ${ }^{36}$ This audacious move resulted in the establishment of L'Hôpital Chirurgical Mobile No. 1, on the road from Dunkirk to Ypres, just seven miles behind the front-line trenches. Doctors, transport, and supplies were provided by the French military medical services, but nursing staff and running costs were funded by Borden herself. ${ }^{37}$ Joffre permitted her to exercise complete control over the nursing work of the hospital, as its 'Directrice. ${ }^{\text {' }}$ '

Borden's earliest unit served the Thirty-Sixth Corps of the French Eighth Army and was composed of long wooden huts that acted as hospital wards, each with twenty beds. One was set up as an operating theatre, with X-ray and dressing rooms; another was a kitchen and store. There was also a 'reception hut', to which wounded men were brought from ambulances to be triaged. Here, decisions were made about how urgent each case was, and from here patients were sent either straight to the operating theatre; to X-ray; to a ward to await treatment; or, for the worst cases, to the moribund ward where only palliative care was given. Borden spend much of her time in the reception hut during the great 'rushes' of casualties that followed unsuccessful assaults on the Western Front. The model of this first reception hut was copied at L'Hôpital d'Evacuation on the Somme Front in 1916, about which Borden wrote one of her most vivid short essays, 'Blind'. ${ }^{39}$ Borden's belief that she had acquired expert clinical observational skills is made clear by this text, in which she explains, in highly poetic terms, the ways in which she assessed her patients and made decisions about their treatment needs. ${ }^{40}$ She also dwells on the joy she felt in knowing that her field hospital had the lowest mortality rate on the French Front. In its first six months, L'Hôpital d'Evacuation treated over 800 cases, with only 68 deaths. ${ }^{41}$ 
Borden moved her children and household from London to 21 Bois de Boulogne in Paris. ${ }^{42}$ She appears to have held evening parties here. Although wartime stringency meant that these in no way resembled the lavish soirées she had held in pre-war London, it was noted by writer Gertrude Stein that Borden's house was one of the few where there was enough fuel to keep warm during the terrible winter of $1915 .{ }^{43}$ It is not clear how well Borden and Stein knew each other, but references in Stein's Autobiography of Alice Toklas suggest that they were fairly close acquaintances, and that Borden visited Stein's salon at the rue de Fleurus on several occasions. ${ }^{44}$ It may have been here that Borden met writer Ellen La Motte, although it is also possible that Stein, Borden, and La Motte already knew each other; all had attended Vassar College at the turn of the century.

Borden's second unit - on the Somme Front - was offered to the French Service de Santé in the autumn of 1916, when it became clear that the fiercest fighting was taking place far to the south of Rousbrugge. By this time, the French military medical services had taken a decision to staff their hospitals only with French nurses, and Borden had great difficulty in persuading the authorities to permit her to establish her second unit, L'Hôpital d'Evacuation, five kilometres behind the front-line trenches, at Bray-sur-Somme. ${ }^{45}$

At L'Hôpital d'Evacuation, Borden had only 12 nurses for 2,000 patients, and was forced to use these to staff wards reserved for the most seriously wounded. The hospital was heavily dependent on the work of orderlies. ${ }^{46}$ It was whilst running L'Hôpital d'Evacuation that Borden met Captain Edward Louis Spears, a liaison officer with the British Expeditionary Force. From the spring of 1917 they were exchanging frequent letters, which show that they had embarked on a passionate and secret love affair. ${ }^{47}$

At the beginning of 1917, Borden's medical team was moved to Villers-sur-Condon, between Soissons and Rheims, in preparation for the Aisne campaign. Here, during the Nivelle offensive, her hospital was damaged by shell-fire. Soon after this, she returned to her original unit at Rousbrugge, which was, in turn, bombarded on 5 June. Several orderlies, one patient, and one nurse were wounded. ${ }^{48}$ The next day, gas shells reached the hospital. Borden had already been awarded the Croix de Guerre in March, and now a 'palm' was added, and was conferred on her by General Pétain in person. A few days 
after this, she was rushed to hospital in Dunkirk - an event that is shrouded in secrecy, but appears to have been due to a miscarriage. A long period of ill health followed, which was complicated by severe pneumonia. Borden attempted to continue working but was obliged to take frequent breaks to rest and convalesce. In February 1918, she suffered another miscarriage. ${ }^{49}$

In the summer of 1917, Borden published some short journal articles; these were later incorporated into her book The Forbidden Zone..$^{50}$ In August, she submitted the full manuscript to Collins, but was instructed by the censor to edit the work, and decided not to go ahead with publication. ${ }^{51}$ During this time, her life was extremely turbulent. Not only was she involved in the running of her field hospitals, and attempting to get her work published; she was also suing her husband for divorce. Proceedings began on 18 December 1917, but led to a prolonged and bitter battle over the custody of the couple's three daughters. ${ }^{52}$

During 1917 Borden's writing for The Forbidden Zone began to take clearer shape. Although the book recounts experiences from both Rousbrugge and Bray-sur-Somme, it is clear that some of the metaphors adopted in the section of the book entitled 'The North' were being developed during Borden's time on the Somme. One in particular offers a complex metaphorical representation of pain as a demonic lover. She also describes pain as a harlot who is 'holding the damp greenish bodies of the gangrene cases in her arms. ${ }^{53}$ The nurse, in the face of such suffering, loses her humanity and her womanhood and becomes 'really dead, past resurrection. ${ }^{54}$ At around the time she was writing these vignettes, Borden enclosed a poem in a letter to Edward Spears, in which a different metaphor is developed - this time pain is a powerful and overwhelming male lover, who claims her as his mistress:

Leave me to this hungry lust

Of monstrous pain. I am his mistress now

These are the frantic beds of his delight

Here I succumb to him, anew, each night..$^{55}$

Borden and Spears married at the British consulate in Paris on 30 March 1918, just days after the commencement of the German offensive ${ }^{56}$ Following the allied victory, the couple continued to live in Paris, keeping 'open house' during the Peace Conference; and 
Borden gave birth to a son, Michael, on 2 March $1921 .{ }^{57}$ Throughout the 1920s, Borden pursued her writing career, publishing a succession of novels. ${ }^{58}$

Mary Borden was a significant female modernist whose work offered a profound insight into the realities of the First World War. ${ }^{59}$ She wrote obsessively, and Jane Conway has attributed to her the statement that writing a book was like having 'an attack of typhoid fever with headaches and fits of depression. ${ }^{60}$ Among her books none is more extraordinary than her semi-fictionalised account of her work at Rousbrugge and Bray-sur-Somme. Having been obliged to shelve The Forbidden Zone in 1917, Borden returned to it at the end of the 1920s - probably for financial reasons ${ }^{61}$ believing that it would match the public mood that was receiving books such as Erich Maria Remarque's All Quiet on the Western Front, and Ernest Hemingway's A Farewell to Arms, with acclaim. ${ }^{62}$ Her confidence was somewhat misplaced; many critics were shocked that a woman should write so frankly about the realities of war. ${ }^{63}$

Borden's main purpose appears to have been to expose the spiritual truths that lay behind the horrors of war. This is not, however, to deny the obviously pacifist intentions of her work. The vignettes she offers are clearly intended also to illustrate the debasing qualities of warfare and the damage it inflicts on human beings. Perhaps one of the best-known excerpts from her book is one in which she depicts the hospital as a laundry where men, like packages of clothes, are processed and returned to the front:

You say that these bundles are the citizens of the town? What do you mean? Those heavy brown packages that are carried back and forth, up and down, from shed to shed, those inert lumps cannot be men. They are delivered to this place in closed vans and are unloaded like sacks and are laid out in rows on the ground and are sorted out by the labels pinned to their covers. They lie perfectly still while they are carried back and forth, up and down, shoved into sheds and pulled out again. What do you mean by telling me that they are men? ${ }^{64}$

Borden adopts a subtly erotic tone as she writes of how the medical staff 'conspire' against a patient's 'right to die. ${ }^{65}$ His purpose has not yet been fulfilled. He must be repaired and sent back to the front line, where he can still be of use against the enemy. He is a passive victim into whose 'innocent wounds' the nurses and doctors stare. The final 
insult comes when the medical staff 'dig into the yawning mouths of his wounds. Helpless openings, they let us into the secret places of his body. To the shame of the havoc of his limbs we add the insult of our curiosity and the curse of our purpose, the purpose to remake him. ${ }^{66}$ The scenario is not only reminiscent of rape - full of what Trudi Tate refers to as 'eroticised horror ${ }^{67}$ - it is also an affront against humanity 'en masse': the repair of one small element of a larger war machine, the purpose of which is not to restore a human being but, rather, to remake a component. What is most disturbing is the patients' gratitude: 'When we hurt them they try not to cry out, not wishing to hurt our feelings. And often they apologise for dying. ${ }^{68}$

Hazel Hutchison has commented on how 'profoundly troubled' Borden was by the 'ironies of nursing in wartime. ${ }^{69}$ These feelings are brought out clearly in writing that is ironic in tone - mocking the ignorance of those who have remained safely at home, away from the realities of the battlefield. Borden possessed remarkable capacity for portraying trauma, in both its physical and its emotional guises. ${ }^{70}$ And yet she was also exhilarated by war service. In the reception hut of her field hospital on the Somme, her hospital 'throbbed and hummed ... like a dynamo' and her emotions were fired by 'a sense of great power, exhilaration and excitement. ${ }^{71}$ Her work is a powerful depiction of what Santanu Das refers to as 'the precipice between the exhilaration of service and the trauma of witnessing.72

Soon after publishing The Forbidden Zone, Borden returned to novel-writing. ${ }^{73}$ As always, she poured her personal experience, feelings, and opinions into her writing, and, as always, her books provoked controversy. A further book, designed to promote and support a greater emotional and sexual freedom for women, The Technique of Marriage, was published in $1933 .^{74}$

At the outbreak of the Second World War, Borden was approached by Lady Hadfield to run a mobile field hospital. The so-called 'Hadfield-Spears Unit' served in North Africa, winning both official recognition and public acclaim. ${ }^{75}$ After her experiences of desert war, Borden, by this time over fifty, returned home to England, where she continued writing both fiction and semi-fictionalised autobiographical work. ${ }^{76}$

Mary Borden died on 2 December 1968 at the age of eighty-two. ${ }^{77}$ She had experienced at first hand some of the most dramatic events 
of the twentieth century and had engaged deeply and personally with one of the most revolutionary social and cultural trends of her time: the emancipation of women. She had claimed the right to perform the work she considered important, divorced her first husband, and fought for custody of her children. In her writings - as in her actions - she claimed a freedom that must, at times, have created discomfort and distress for those around her, yet she won the respect and admiration of many who knew her. Mary Borden seems to have wanted to be a woman of truth rather than compromise, and her truth can be read most forcibly through her astounding record of two of her First World War field hospitals. The Forbidden Zone confronts its readers with some of the most shocking realities of war.

\section{Agnes Warner: devoted professional}

In the winter of 1915/16 there were four Canadian nurses at L'Hôpital Chirurgical Mobile No. 1. Three were Army Nursing Sisters, who had been placed with the hospital by the FFNC. The other was a former probationer of the New York Presbyterian Hospital, who had travelled to France as a private nurse and become involved in the French war effort. This fourth nurse, Agnes Warner, is still remembered in the twenty-first century in her home town of Saint John, New Brunswick. She was, in the second decade of the twentieth century, one of its most celebrated daughters. ${ }^{78}$ The town's small library and archive has a file on her, and local historians incorporate her story into their guides. Daughter of a famous father, Warner won the respect and admiration of her own contemporaries, largely because of the way in which her wartime work (which was actually not so different from the work of thousands of other nurses) was celebrated in the local press as a succession of 'deeds' and 'exploits. ${ }^{79}$

Agnes Warner's father, Darius, had been a general in the Union Army during the American Civil War. Having been seriously wounded, he retired from military service and was made American Consul to the strategically important Canadian town of Saint John. ${ }^{80}$ He won the respect of the townspeople for his authoritative and compassionate handling of the great fire of $1877,{ }^{81}$ and it is quite possible that his second daughter, Agnes, was drawn to nursing, and ultimately to the nursing of wounded soldiers, by her upbringing in a 


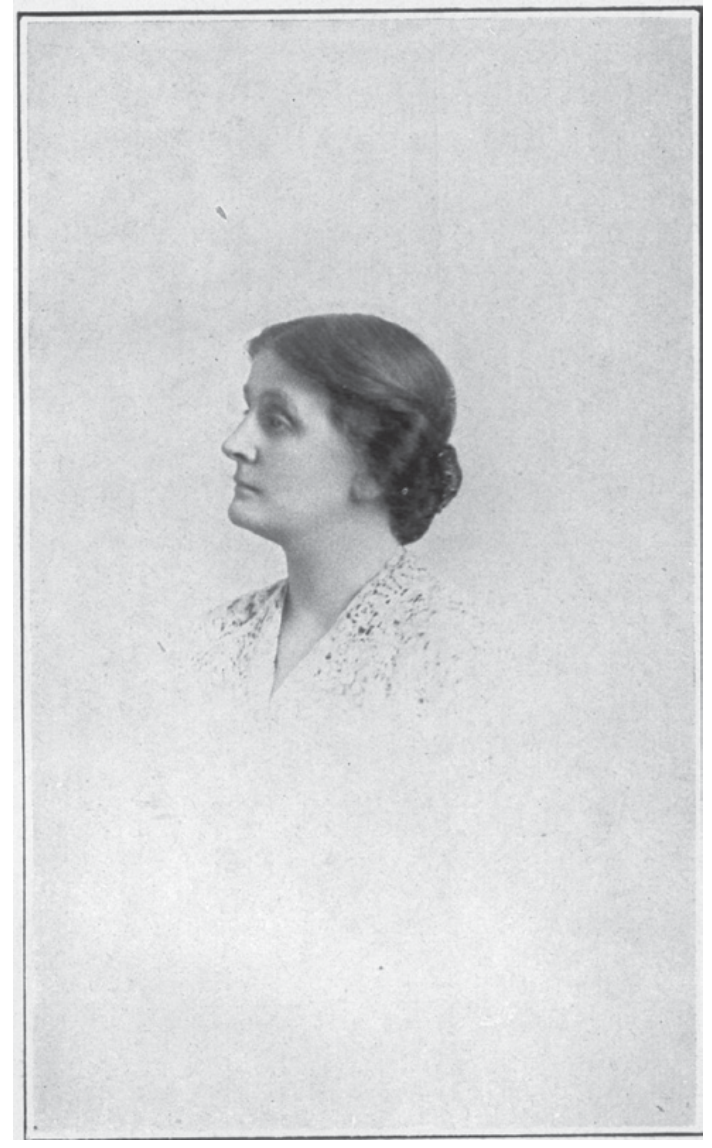

Figure 3 Portrait of Agnes Warner

family in which public service was highly valued, and where doing 'great deeds' was something to be lived out rather than read about in novels. ${ }^{82}$ As she lived her own 'great adventure', she wrote letters home describing her experiences and feelings as a Canadian-born, American-trained nurse caring for the French wounded, first in a temporary hospital in the Alsatian town of Divonne-les-Bains, and secondly at L'Hôpital Chirurgical Mobile No. 1 in Rousbrugge and at other locations in Belgium. Warner's letters home were collected by 
her mother and sisters, and passed, without her knowledge, to a local Saint John publisher, N. B. Barnes. My Beloved Poilus, a collection of these letters - offering tantalising glimpses of her life and work was published in 1917, while she was still serving as head nurse at L'Hôpital Chirurgical Mobile No. $1 .^{83}$

Warner's letters were widely read, highly celebrated, and, ultimately, were published because of the social circle in which she moved. As members of one of New Brunswick's most prominent families, she and her sisters attended parties and events organized by other upper-middle-class ladies of their own 'set', and joined one of the most prominent chapters of the influential 'Independent Order of the Daughters of the Empire, an elite patriotic society that flourished at the turn of the century and operated as a significant promoter of the Canadian war effort. ${ }^{84}$ In Saint John alone, there were six chapters of the Daughters of the Empire; Warner's work gained particular financial and practical support from the Demonts Chapter. One local newspaper article, which reported on her wartime work, offered a somewhat hyperbolic account of the patriotic feeling with which the Order was infused: 'As broad as the empire upon which the sun never sets - as deep as the great oceans which girdle it - as high as the aspirations of the heroic sons who have laid down their lives in its defence stands the order of the Daughters of Empire. ${ }^{85}$

Agnes Warner, unlike the other female members of her family, appears never to have intended to remain at home in Saint John. She attended McGill University, Montreal, graduating in natural sciences in 1894 and giving a valedictory lecture to her year group, in which she commented that the day was past when women were laughed at for their ignorance and yet denied the right of a good education. ${ }^{36}$ After graduating, in 1902, from the renowned New York Presbyterian Hospital School of Nursing, she became private nurse and companion to a wealthy, elderly Long Island couple, $\mathrm{Mr}$ and Mrs Roswell Eldridge, and spent much of the early part of the twentieth century travelling with them through Europe. ${ }^{87}$ At the beginning of August, she was with her employers in the southern French spa town of Divonne-les-Bains. She wrote to her mother: 'August 2, 1914: the awful war we have all been dreading is upon us - France is mobilizing ... We have started teaching the women and girls to make bandages, sponges, etc., for the hospital which will be needed here. ${ }^{88}$ On 23 August, she wrote of her 
admiration for the French people and of her decision to help in the Red Cross hospital that was being created. ${ }^{89}$

Warner travelled back to New York with the Eldridges and spent Christmas 1914 in Saint John with her family. She then returned to France, and spent a few months working at the American Ambulance in Paris. ${ }^{90}$ This may have been where she met Mary Borden, and was invited to consider joining the ranks of L'Hôpital Chirurgical Mobile No 1.

On 19 February 1915, she was back again in Divonne-les-Bains, and was writing to her mother: 'I have thirteen patients, nine in bed all the time, and the others up part of the day. One of the women of the village helps me in the morning, two others help with the cleaning up and serving meals; everything has to be carried up three flights of stairs, so you can imagine the work. ${ }^{31}$ The workload was, indeed, onerous for a woman of Warner's age, ${ }^{92}$ yet a close reading of her letters reveals how convinced she was of the justice of the allied cause and how deep and genuine was her desire to help the French people. On 25 April she commented: 'We have been very busy all week, new patients coming every day till now we have forty. Most of them are not wounded. Poor fellows, they are utterly done out; some have pneumonia, others rheumatism, one paralyzed and all sorts of other things. ${ }^{93}$

In May, following another visit to Paris, Warner returned to find 'two new patients, one with a leg as big as an elephant and the other out of his head. ${ }^{94}$ Soon after this, in early June the French military authorities decided to enlarge the hospital, make it a semi-military institution of 400 beds, and invite Warner to take charge. Days later, she heard that Canadian troops had left Saint John - her own nephew among them - and expressed mixed feelings: patriotic pleasure that her countrymen were assisting the war effort; and fear at their likely fate. ${ }^{95}$

Within months, Warner was writing of her impending move to join L'Hôpital Chirurgical Mobile No. 1 in Belgium, expressing pleasure at the prospect of being so close to the firing line, and, in particular, 'nearer the Canadian boys. ${ }^{96}$ In September, she wrote:

Mobile No.1, France, 1915. I am really not in France but Belgium. I cannot tell you just where, but it is within ten miles of the firing line, and not far from the place where so many of our boys from home have been sent ... The first night I arrived I did not sleep, for the guns roared all night long, and we 
could see the flashes from the shells quite plainly; the whole sky was aglow. The French and English guns sounded like a continuous roar of thunder; but when the shells from the German guns landed on this side we could feel a distinct shock, and everything in our little shanty rattled ... There are about one hundred and fifty beds in all here. ${ }^{97}$

Life at L'Hôpital Chirurgical Mobile No. 1 was not easy. On 5 December, Warner was writing that: 'last night we had the most awful wind storm. I thought our little hut would be carried over into the German lines. It rained in torrents and the roof leaked, and I could not get my bed away from the drips, so I put up my umbrella.98 Later, in March 1916, she recounted: 'another awful storm ... wind and rain. Windows blew off and doors blew in, and one poor little night nurse was blown off the sidewalk and nearly lost in the mud. ${ }^{9}$

Warner's phlegmatic indifference to discomfort seems to have been an integral part of her psyche. Stoicism and determined good cheer are typical of nurses who adopted a traditional style of writing. ${ }^{100}$ In Warner's case, there can be little doubt that the positive gloss she places on her experiences - the sense that, really, the discomfort is all part of a 'great adventure' - is heavily influenced by the anticipated primary reader of her letters: her mother. During the war, many 'letters home' by both combatants and nurses were written in full recognition that they were likely to find their way into multiple hands and be read by a large circle of family and friends. ${ }^{101}$ In the days before technology, the writing and reading of letters was seen as an aesthetic pleasure to be shared, and letters from war participants were particularly highly prized. Still, Warner probably never anticipated that letters intended for a close family audience would be published and distributed throughout her province. A clue to her feelings when she heard of their publication may be found in an unidentified newspaper clipping, dated 28 April 1917, which has been pasted into a fourth-edition copy of My Beloved Poilus and which quotes one of Warner's later letters:

It was awfully good to take so much trouble to have my stupid letters published and I am more than delighted to get the money for My Beloved Poilus (soldier) $[s i c]$... I must say it was an awful shock when I first received it, but if the people are interested, in spite of the appalling English, and it sells well, I must not mind. You know I did not even have 
time to read over my letters and they are rather a disgrace to a graduate of McGill. ${ }^{102}$

Warner's book attracted great attention in her own province of New Brunswick, ${ }^{103}$ bringing not only funds from sales, but also donations of many kinds, ranging from 'yarn for French peasants to make into socks for the soldiers, ${ }^{104}$ to boxes of surgical supplies. ${ }^{105}$ Warner's hut at L'Hôpital Chirurgical Mobile No. 1 came to be known as the 'high class bazaar', as she amassed a range of useful objects for the hospital. ${ }^{106}$

It is easy for a modern readership, steeped in later perspectives on the futility of the First World War, to condemn the apparently propagandist nature of Warner's writing. The lectures and journalistic interviews she gave on her brief visit home in December 1914 clearly highlighted stories of German atrocities that had been circulating in France during the early months of the war, and offered a poignant image of the beleaguered heroism of the French people. Whether such outputs were deliberately intended to encourage young Canadian men to enlist is doubtful. It is more likely that Warner's passionate involvement with the French people compelled her to write and speak as she did.

In February, 1916 Warner commented:

We are so busy here that we scarcely know where to turn. It is just a procession of wounded coming and going all the time, for we have to send them off as quickly as possible in order to make room for the new arrivals. Thirty-eight went off last Tuesday and fifteen on Friday, but the beds are filled up again. The last ones we have been getting are so badly wounded that I wonder who can be moved on Tuesday. ${ }^{107}$

On 20 March 1916, Warner commented that she had been left in charge of the field hospital, adding that supervising an entire staff composed of French, English, American, Canadian, and Australian nurses was making her nervous. ${ }^{108}$ Later that summer, she announced that 'Mrs T is going to organize another hospital on the Somme and is going to keep this one as well', adding, 'She certainly has done a splendid work.' ${ }^{109}$

It was not only their patients who were delighted with the nurses at 'le petit paradis'. Their French doctor colleagues commented on the 'dedication' of these professional co-workers. Their letters were hungrily collected and avidly reported by Ethel Gordon Fenwick, editor 
of the British Journal of Nursing - a keen campaigner for nurses' professional status. In January 1917 a letter received by Grace Ellison was published in the journal:

I cannot refrain from writing to thank you for the English nurses who have been sent here. From the technical point of view it would be impossible not to appreciate them, the only thing one can say is that, thoroughly understanding and loving their work as they do, they have been able to replace the doctor in so many ways ... And added to this, I have found in the Sisters a frank, simple gaiety which greatly helps towards recovery of the poor wounded. ${ }^{110}$

In April 1917, in a dramatic incident, the hospital was subjected to bombardment from the air, and one of its Canadian nurses, Madeleine Jaffray, was severely wounded. Both Jaffray, and colleague Hilda Gill, who came to her rescue, were awarded the Croix de Guerre, a decoration normally reserved for French combatants. As Jaffray recovered in a Belgian field hospital, she received a visit from Violetta Thurstan, matron at the nearby Hôpital de l'Océan, who reported back to Ethel Gordon Fenwick: 'I have just been to see your wounded French Flag Nurse, Miss Jaffray ... I am glad to say she is as well as can be expected and is suffering a good deal less today.' ${ }^{111}$ Jaffray was, eventually, transferred to the American Ambulance in Paris, where bone-grafting surgery was performed on a wounded foot. ${ }^{112}$ For their loyalty and fortitude during this air raid, all the nursing staff of the hospital received the French Insigne, an accolade that was also enthusiastically reported by the British Journal of Nursing. ${ }^{113}$

In the spring of 1918, during the rapid German advance, the hospital's position became even more hazardous, and - for their own safety - its nursing personnel were moved back to Forge-les-Eaux, well behind the lines. While there, Warner received a letter from a former surgeon colleague, now working close to the front without any nursing staff:

We worked all night hoping some rest for the day after, but the arrivage [sic] was about 2,000 and every day like that during ten days. For five days Messr R. (chief surgeon) and I were alone. We asked for you the first day. No compresses, no towels for the operations, amputations or debridgements [sic]. Extractions of projectiles were made on the brancards (stretchers) often without an anaesthetic. How many poor chaps died without care! How many would not be dead if you had been here! ${ }^{114}$ 
A small group of five nurses - Warner among them - campaigned to be posted back to the front lines with their hard-pressed medical colleagues. After several weeks of waiting and working at the American Ambulance in Paris, their request was granted and they were placed with Ambulance 16/21, a unit serving the Thirty-Sixth Corps of the French army. ${ }^{115}$ As part of this unit, Warner and her colleagues followed the allied advance into the occupied zones. They established makeshift hospitals in tents, ruined chateaux, and schools, and cared for military casualties, former prisoners- of-war, and civilian patients. On one occasion, they salvaged a stove on which to do their cooking, only to find that it had been filled with hand grenades. ${ }^{116}$ One of the nurses, in a letter to the British Journal of Nursing, commented on the plight of former prisoners: 'their condition is truly pitiful. Covered with vermin, just skin and bone. Their joy at being with us and having decent food to eat was enough to reduce one to tears. ${ }^{117}$ Ambulance $16 / 21$ was said to have been one of the first hospital units to cross the Hindenburg Line and to follow the advancing allied armies into Germany. ${ }^{118}$

On 21 December 1918, four sisters of Ambulance 16/21 were decorated with the Croix de Guerre. Warner, who had already been awarded the Medaille des Epidémies and the Medaille d'Honneur en Bronze, ${ }^{119}$ received the following citation:

Miss Warner (Agnes Louise) Infirmière Major, Ambulance 16.21, has been in the 'formations sanitaires' of the French Armies for four years, where she is well known as a model of enduring energy, of disinterestedness and of devotion. Spent day and night attending to gassed and severely wounded cases, regardless of fatigue and bombardments. Has commanded the admiration of all. ${ }^{120}$

Agnes Warner returned to her home town of Saint John in March 1919 to a heroine's welcome. ${ }^{121}$ Invited by every significant female institution in the town - from her former high school to the Women's Canadian Club - to give public lectures on her wartime experiences, Warner was feted and showered with flowers and gifts. She became, for a short time, a focal point for Saint John's outpouring of post-war patriotism; flags were displayed; national anthems played; and red, white, and blue bouquets presented. ${ }^{122}$ And Warner embraced her role at the heart of this nationalist fervour. At one reception, given by 
the Royal Standard Chapter of the Daughters of Empire, she spoke of how 'she had seen her wounded Poilus suffer such unbelievable things with courage, fortitude, endurance and resignation in order that freedom and liberty might prevail'. ${ }^{123}$ A Daily Telegraph reporter who heard her speak at a Canadian Club special luncheon believed that 'she must indeed have been an angel of mercy to the wounded', commenting on how 'many of her hearers were scarcely able to restrain their tears. ${ }^{124}$ Warner's lectures were infused with anti-German propaganda. One reporter who heard her 'address' at the Baptist Institute referred to 'the devlish cruelty of the Germans. ${ }^{125}$ The sincerity of this message and its heartfelt emotionalism were clearly its most powerful traits.

Agnes Warner died of breast cancer at the New York Presbyterian Hospital on 23 April 1926 at the age of fifty-four. A lengthy obituary in the Saint John Globe emphasised her war service and her medals and honours, quoting the citation for her Croix de Guerre: 'a fait l'admiration de tous'. It reads like so many outpourings of the early inter-war period, finding meaning in patriotic duty and service:

Miss Warner, the quiet beauty of whose life and whose fine scholarship were in themselves notable contributions to the community in which she lived and to those with whom she was daily associated. Her name lives in France: her services are recorded in its military records and her story as told in My Beloved Poilu [sic] is among the French Archives. On the Roll of Honour [sic] in the Saint John High School, on that of McGill University and of the New York Presbyterian Hospital her name is among those that will live forever because she heard and always answered when and wherever duty called. ${ }^{126}$

\section{Conclusion: the 'Directrice' and the head nurse}

Although celebrated in her home town of Saint John and well known in her own time, Agnes Warner has not survived well in the historical record. Whilst much has been written about the wealthy philanthropist Mary Borden - founder of L'Hôpital Chirurgical Mobile No. 1 - less is known about the astute head nurse who kept her extraordinary hospital alive. Borden's memory survives because of the artistry of her own writing. Renowned as a literary modernist, her work has achieved scholarly acclaim. ${ }^{127}$ Warner's simple letters to her mother 
delighted a parochial readership in her own time, but had little impact on a wider academic audience and failed to find a significant place in the historical record. In her Journey down a Blind Alley, Mary Borden referred fleetingly to 'frail Miss Warner with her eye-glasses and grey hair'128 - a vague and passing mention of a woman to whom she probably owed much of her own wartime success. Such are the vagaries of the historical record.

\section{Notes}

1 For a list of volunteer units that formed part of the British Army Medical Establishment on the Western Front, see: Iain Gordon, Lifeline: A British Casualty Clearing Station on the Western Front, 1918 (Stroud: History Press, 2013).

2 Mary Borden, Journey down a Blind Alley (London: Hutchinson, 1947 [1946]): 9; Margaret Higonnet, Nurses at the Front: Writing the Wounds of the Great War (Boston, MA: Northeastern University Press, 2001): x; Hazel Hutchison, 'The Theater of Pain: Observing Mary Borden in The Forbidden Zone', in Alison S. Fell and Christine E. Hallett (eds), First World War Nursing: New Perspectives (New York: Routledge, 2013): 139-55; Shawna Quinn, Agnes Warner and the Nursing Sisters of the Great War (Fredericton, NB: Goose Lane Editions with New Brunswick Military Heritage Project, 2010): 51.

3 Borden was a prolific writer. Her earliest novels had been written under the pseudonym Bridget Maclagan. See, for example: Bridget Maclagan, The Mistress of Kingdoms; or, Smoking Flax: A Novel (London: Duckworth, 1912); Bridget Maclagan, Collision (London: Duckworth, 1913); Mary Borden, The Romantic Woman: By Bridget Maclagan - Mary Borden Turner (London: Constable, 1924 [1916]); Mary Borden, Jane - Our Stranger: A Novel (London: William Heinemann, 1923).

4 Laurence Binyon, For Dauntless France: An Account of Britain's Aid to the French Wounded and Victims of the War. Compiled for the British Red Cross Societies and the British Committee of the Red Cross (London: Hodder and Stoughton, 1918): 156-7.

5 Borden, Journey down a Blind Alley: 9; Anon., 'Nursing and the War', BJN (30 September 1916): 269.

6 It appears that the hospital's first move was in April 1917, and that this took it closer to the French lines. Subsequent moves - as a result of direct hits by enemy shelling - took place later in 1917, and in 1918. Anon., Column, BJN (14 April 1917): 254; Anon., Column, BJN (6 April 1918): 241; Binyon, For Dauntless France: 156-7.

7 Borden, Journey down a Blind Alley: 9. 
8 Grace Ellison, 'Nursing at the French Front', in Gilbert Stone (ed.), Women War Workers: Accounts Contributed by Representative Workers of the Work Done by Women in the More Important Branches of War Employment (London: George G. Harrap, 1917): 155-80.

9 Ellison, 'Nursing at the French Front': 162.

10 The French Red Cross was composed of three societies: the Société de Secours aux Blessés Militaires, the Union des Femmes de France, and the Association des Dames Françaises: Ellison, 'Nursing at the French Front': 159.

11 Ellison, 'Nursing at the French Front': 159-60.

12 Ellison, 'Nursing at the French Front': 162.

13 Anne Summers, Angels and Citizens: British Women as Military Nurses, 1854-1914, rev. edn (Newbury: Threshold Press, 2000).

14 Anon., 'Is It Just?', in 'Letters to the Editor', BJN (4 July 1914): 22; Anon., 'Letters to the Editor', BJN (19 December 1914): 497; Anon., 'The Nursing Outlook: War Fever and the War Spirit', The Nursing Mirror and Midwives Journal 19 (22 August 1914): 397. On the FFNC, see: Christine E. Hallett, Veiled Warriors: Allied Nurses of the First World War (Oxford: Oxford University Press, 2014): Chapter 1.

15 Ellison, 'Nursing at the French Front': 163.

16 Ethel Gordon Fenwick, as owner and editor of the BJN, used the columns of her journal to promote the work of the FFNC. A regular column on the work of the corps appeared throughout the war from 24 October 1914 onwards. For examples of references to the work of FFNC nurses at L'Hôpital Chirurgical Mobile No. 1, see: Anon., 'Nursing and the War' (30 September 1916); Anon., 'French Flag Nursing Corps', BJN (14 April 1917): 254; Anon., 'French Flag Nursing Corps', BJN (23 June 1917): 434; Anon., 'Decorations for Nurses', BJN (30 June 1917): 452; Anon., 'French Flag Nursing Corps', BJN (16 February 1918): 113.

17 Ellison, 'Nursing at the French Front': 164.

18 These included trained nurses from the British dominions, particularly Canada and Australia. American volunteers were also recruited - though not through the FFNC. On the recruitment of FFNC nurses to L'Hôpital Chirurgical Mobile No. 1, see: Anon., 'French Flag Nursing Corps', BJN (26 May 1917): 361, 362. Jane Conway reports that the hospital initially had seventeen staff, composed of nurses, doctors, and orderlies: Jane Conway, Mary Borden: A Woman of Two Wars (Chippenham: Munday Books, 2010): 47.

19 There is a description of the hospital (sixteen huts, composed of wards, a 'salle des entrées', a 'salle des opérations', a 'salle de pansements', kitchen, laundry, and linen room), in: Anon., 'Hôpital Mobile No. 1', BJN (16 September 1916): 232-3. For references to certain aspects of work at the hospital, see: Higonnet, Nurses at the Front: Introduction; Ariela Freedman, 'Mary Borden's Forbidden Zone: Women's Writing from No-Man's Land', Modernism/ Modernity, 9.1 (2002), 109-24; Quinn, Agnes Warner. 
20 Mary Borden, The Forbidden Zone (London: William Heinemann, 1929).

21 Borden, The Forbidden Zone: preface.

22 Ellen N. La Motte, The Backwash of War: The Human Wreckage of the Battlefield as Witnessed by an American Hospital Nurse (New York: G. P. Putnam's Sons and The Knickerbocker Press, 1916).

23 Anon., My Beloved Poilus (Saint John, NB: Barnes, 1917).

24 Maud Mortimer, A Green Tent in Flanders (New York: Doubleday, Page, 1918). On the 'Golden Godmother and Directress' of the hospital, see pp. 60 and 68; on the nursing staff, see pp. 67 and 69-71; on the cynical nurse writer she refers to as 'Organization', see pp. 156-8. One of the most compelling pieces of evidence for the likelihood that Mortimer's book refers to L'Hôpital Chirurgical Mobile No. 1 is her recounting of an incident in which the nurses of the hospital care for a young woman in the neighbouring village who has severe burns (pp. 199-210). The same incident is recounted by Agnes Warner in: Anon., My Beloved Poilus: 91. The details of the incident are remarkably similar, and both accounts place it towards the end of February 1916.

25 Borden, The Forbidden Zone: 115.

26 Mortimer, A Green Tent in Flanders: 198.

27 La Motte, The Backwash of War: vi.

28 Jane Conway suggests that Borden had an affair with Percy Wyndham Lewis in the spring of 1914, and it is likely that her own writing - particularly in The Forbidden Zone - was heavily influenced by Wyndham Lewis: Conway, Mary Borden: 32-6. Angela Smith locates Borden's writing with the 'post-war culture of despair' that characterised the modernists, particularly Wyndham Lewis: Angela Smith, The Second Battlefield: Women, Modernism and the First World War (Manchester: Manchester University Press, 2000): 84.

29 Conway, Mary Borden: 11.

30 In her early and largely biographical novel The Romantic Woman, Borden explores these early influences on her life: Borden, The Romantic Woman: 25-6.

31 Conway, Mary Borden: 15-22.

32 Conway, Mary Borden: 23-7.

33 Conway, Mary Borden: 29-30.

34 Conway, Mary Borden: 31 . Conway is citing, though not directly quoting, E. M. Forster.

35 It may have been because of this experience that, when she later formed her own field hospital, she insisted that the nursing must be done only by fully trained nurses. On Borden's experience in the typhoid hospital, see: Conway, Mary Borden: 39-41.

36 Borden, Journey down a Blind Alley: 9.

37 Because a unit of the FFNC was based at Borden's field hospital, several articles in the BJN refer to it. See, for example: Anon., 'French Flag Nursing Corps', BJN (29 April 1916): 378; Anon., 'French Flag Nursing Corps', BJN (27 May 1916): 458; Anon., 'Hôpital Mobile No. 1'; Anon., Column, BJN (20 
January 1917): 41; Anon., Column, BJN (14 April 1917); Anon., 'French Flag Nursing Corps' (26 May 1917): 361. See also: Conway, Mary Borden: 45.

38 Conway, Mary Borden: 41-2.

39 This essay was incorporated into Borden, The Forbidden Zone: 136-59.

40 Christine Hallett, Containing Trauma: Nursing Work in the First World War (Manchester: Manchester University Press, 2009): 28.

41 Conway, Mary Borden: 47.

42 Conway, Mary Borden: 43.

43 Gertrude Stein, The Autobiography of Alice B. Toklas (London: Penguin, 2001 [1933]): 185. See also: James R. Mellow, Charmed Circle: Gertrude Stein and Company (London: Phaidon Press, 1974).

44 Stein, The Autobiography of Alice B. Toklas: 185.

45 Anon., Column, BJN (30 September 1916): 269.

46 Conway, Mary Borden: 53-5.

47 On her meeting with Louis Spears, see: Borden, Journey down a Blind Alley: 9. See also: Conway, Mary Borden: 65.

48 See the report in BJN: Anon., 'Croix de Guerre for Sister Jaffray', BJN (16 June 1917): 416.

49 Conway, Mary Borden: 71-3, 89.

50 Several sections of the book appeared in The English Review in August 1917: Mary Borden-Turner, 'At the Somme', The English Review (August 1917): 97-102. On Mary Borden's writing in The Forbidden Zone, see: Hutchison, 'The Theater of Pain'; Margaret Higonnet, 'Cubist Vision in Nursing Accounts', in Fell and Hallett, First World War Nursing: 156-72.

51 Conway, Mary Borden: 77.

52 Conway, Mary Borden: 80-8, 102.

53 Borden, The Forbidden Zone: 59.

54 Borden, The Forbidden Zone: 59.

55 Mary Borden, letter to Edward Spears, Churchill Archives, Churchill College, Cambridge, SPRS files 1-3, SPRS 11/1/1.

56 Anon., Column, BJN (6 April 1918): 241.

57 Conway, Mary Borden: 94, 104.

58 Mary Borden, Jericho Sands: A Novel (London: William Heinemann, 1925); Four O'Clock and Other Stories (London: William Heinemann, 1926); Flamingo; or, The American Tower (London: William Heinemann, 1927); Jehovah's Day (London: William Heinemann, 1928); The Woman with White Eyes (London: William Heinemann, 1930); Action for Slander: A Novel (London: William Heinemann, 1936); The Black Virgin: A Novel (London: William Heinemann, 1937); Passport for a Girl (London: William Heinemann, 1939).

59 Smith, The Second Battlefield; Higonnet, Nurses at the Front; Margaret Higonnet, 'Authenticity and Art in Trauma Narratives of World War I', Modernism/Modernity, 9.1 (2002): 91-107; Freedman, 'Mary Borden's Forbidden Zone'. 
60 Conway, Mary Borden: 140.

61 Conway, Mary Borden: 149-50.

62 Erich Maria Remarque, All Quiet on the Western Front, trans. Brian Murdoch (London: Vintage, 1996 [1929]); Ernest Hemingway, A Farewell to Arms (London: Arrow, 1994 [1929]).

63 Laurie Kaplan, 'Deformities of the Great War: The Narratives of Mary Borden and Helen Zenna Smith', Women and Language, 27.2 (2004): 35-43.

64 Borden, The Forbidden Zone: 114.

65 Borden, The Forbidden Zone: 119.

66 Borden, The Forbidden Zone: 120.

67 Trudi Tate, Modernism, History and the First World War (Manchester: Manchester University Press, 1998): 84. Angela Smith also comments on the 'metaphoric rape' in this passage: Smith, The Second Battlefield: 90.

68 Borden, The Forbidden Zone: 121.

69 Mary Borden, The Forbidden Zone, ed. Hazel Hutchison (London: Hesperus Press, 2008 [1929]): xiii.

70 Freedman, 'Mary Borden's Forbidden Zone'; Higonnet, 'Authenticity and Art'; Hallett, Containing Trauma: 28, 40, 66, 68, 93, 103, 162, 183-5.

71 Borden, The Forbidden Zone: 146.

72 Santanu Das, Touch and Intimacy in First World War Literature (Cambridge: Cambridge University Press, 2005): 221.

73 Mary Borden, Sarah Gay (London: William Heinemann, 1931); Mary of Nazareth (London: William Heinemann, 1933); The King of the Jews (London: William Heinemann, 1935).

74 Mary Borden, The Technique of Marriage (London: William Heinemann, 1933).

75 Borden, Journey down a Blind Alley; Conway, Mary Borden: 213-78.

76 Borden wrote several commercially successful novels after the Second World War: Mary Borden, No. 2 Shovel Street: A Novel (London: William Heinemann, 1949); For the Record (London: William Heinemann, 1950); Martin Merriedew (London: William Heinemann, 1952); Margin of Error (London: William Heinemann, 1954); The Hungry Leopard (London: William Heinemann, 1956).

77 Conway, Mary Borden: 312.

78 On Agnes Warner, see: Quinn, Agnes Warner.

79 Three local Saint John newspapers each published articles on Warner's work in France, based on her letters, and on a series of public addresses she gave following her return from the war: the Saint John Globe, the Saint John Standard, and the Daily Telegraph. All are available at the Saint John Archives, Saint John, New Brunswick, Canada.

80 Anon., 'General Warner', Saint John Globe (27 February 1917: 4); Anon., 'General D. B. Warner, War Veteran', Saint John Globe (27 February 1917): 10; Anon., obituary for General Darius B. Warner, Daily Telegraph (28 February 1917): 7. 
81 Quinn, Agnes Warner: 41.

82 Agnes Warner was the third of six siblings: one older brother died in infancy before she was born; one younger brother died in early childhood in 1877 . Quinn, Agnes Warner: 41.

83 Anon., My Beloved Poilus.

84 Katie Pickles, Female Imperialism and National Identity: Imperial Order of the Daughters of the Empire (Manchester: Manchester University Press, 2002).

85 Anon., Article, Daily Telegraph (23 December 1916): 9.

86 Anon., Announcement, Saint John Globe (2 May 1894). Warner appears to have had a great interest in botany - an interest that was probably nurtured during her schooling at the Victoria High School for Girls, Saint John. George Upham Hay, the school principal, was a prime mover in the New Brunswick Natural History Society. Warner amassed a large collection of plants, which are stored at the Herbarium of the New Brunswick Museum, Saint John, New Brunswick. I am indebted to Stephen Clayden, curator of the museum, for numerous insights into Warner's early life. See: Stephen R Clayden, 'Hay, George Upham', in George Williams Brown, David M. Hayne, Francess G. Halpenny, and Ramsay Cook (eds), Dictionary of Canadian Biography, Vol. XIV (Toronto: Toronto University Press, 1998).

87 The Alumni Quarterly of the New York Presbyterian Hospital School of Nursing placed Agnes Warner in Paris on a number of occasions, including 1906 and 1907. It is likely that she travelled frequently to France during the first decade of the twentieth century: Anon., Notation, New York Presbyterian Hospital Alumni Quarterly, 1 (July 1906). I am indebted to Shawna Quinn for drawing my attention to this volume. See also: Quinn, Agnes Warner: 43-5.

88 Anon., My Beloved Poilus: 5.

89 Anon., My Beloved Poilus: 7-8. On her return to Canada in December 1914, Warner gave a talk to the townspeople of Saint John emphasising the heroism and endurance of the French people: Anon., 'Red Cross Nurse from Front on Visit Here Tells of War's Horrors', Daily Telegraph (26 December 1914): 12. See also: Anon., Society Page, Daily Telegraph (26 December 1914): 6; Anon., 'Miss Warner on Her Way Back to the Front', Daily Telegraph (14 January 1915): 10; Anon., Society Page, Daily Telegraph (16 January 1915): 10.

90 Anon., My Beloved Poilus: 9-13.

91 Anon., My Beloved Poilus: 14.

92 Warner was forty-two at the outbreak of war and forty-seven by the time she returned home to Saint John.

93 Anon., My Beloved Poilus: 24.

94 Anon., My Beloved Poilus: 31.

95 Warner's nephew, Bayard Coster, survived the war.

96 Anon., My Beloved Poilus: 56. 
97 Anon., My Beloved Poilus: 59-61. Another Canadian nurse, Margaret Hare, based in Poperinghe, wrote of having met Warner: Anon., Article, Saint John Globe (12 July 1916): 3.

98 Anon., My Beloved Poilus: 74.

99 Anon., My Beloved Poilus: 95.

100 Many unpublished nurses' accounts have this determinedly cheerful tone. See, for example: Miss Bickmore, MS essay, 3814; 85/51/1, Imperial War Museum, London; H. M. Harpin, MS letters, 3051 Con Shelf, Imperial War Museum, London; Mrs I. Edgar (née Layng), letters and diary, P211, Imperial War Museum, London.

101 Christine Hallett, 'The Personal Writings of First World War Nurses: A Study of the Interplay of Authorial Intention and Scholarly Interpretation, Nursing Inquiry, 14.4 (2007): 320-9; Christine Hallett, 'Portrayals of Suffering: Perceptions of Trauma in the Writings of First World War Nurses and Volunteers, Canadian Bulletin of Medical History, 27.1 (2010): 65-84.

102 I am indebted to Shawna Quinn for forwarding me this quotation. See also the frontispiece to Anon., My Beloved Poilus, which states that Warner's letters were 'published by her friends without her knowledge, simply and solely to raise money to aid her in her work'.

103 Anon., Society Page article about My Beloved Poilus, Daily Telegraph (24 February 1917): 9; Anon., Society Page note, Daily Telegraph (10 March 1917): 12.

104 Anon., Society Page note, Daily Telegraph (7 October 1916): 12.

105 Anon., Society Page note, Daily Telegraph (16 January 1915): 10; Anon., Article, Daily Telegraph (19 January 1915): 3; Anon., Note, Daily Telegraph (6 February 1919): 7.

106 Anon., My Beloved Poilus.

107 Anon., My Beloved Poilus: 86.

108 Anon., My Beloved Poilus: 93.

109 Anon., My Beloved Poilus: 112.

110 Anon., Column, BJN (20 January 1917). See also: Anon., 'Praise for Unit 16/21', BJN (1 February 1919): 66.

111 Anon., 'Croix de Guerre for Sister Jaffray'.

112 Anon., 'French Flag Nursing Corps' (23 June 1917).

113 Anon., 'Decorations for Nurses'; Anon., 'French Flag Nursing Corps', BJN (16 February 1918): 113.

114 Anon., 'Miss Warner Speaks at Reception'.

115 Anon., 'French Flag Nursing Corps', BJN (3 August 1918): 80-81; Anon., 'French Flag Nursing Corps', BJN (19 October 1918): 234.

116 Anon., 'Miss Warner Speaks at Reception'.

117 Anon., 'French Flag Nursing Corps: En Avant', BJN (14 December 1918): 363 . 
118 Anon., 'First Nursing Unit over Hindenburg Line', Saint John Globe (7 December 1918): 5.

119 On Warner's decorations, see: Anon., 'War's Lessons Should Not Soon Be Forgotten', Daily Telegraph (11 April 1919): 3; Anon., 'Obituary', Saint John Globe (26 April 1926: 3); Anon., 'Spent Five Years of Nursing among the French Soldiers', Saint John Standard (31 March 1919): 3.

120 Sister Hilda Gill, who had already been decorated with the Croix de Guerre for her rescue of Sister Jaffray in 1917, was also recognised with a further decoration: Anon., 'French Flag Nursing Corps', BJN (4 January 1919): 6-7. See also: Anon., 'Miss Warner Gets Croix de Guerre', Saint John Globe (11 January 1919): 12.

121 Anon., Column, Daily Telegraph (1 March 1919): 2; Anon., 'Miss Agnes Warner Is Expected Soon', Daily Telegraph (3 March 1919): 4.

122 Anon., Society Page, Daily Telegraph (12 April 1919): 12; Anon., Column, Daily Telegraph (25 April 1919): 3; Anon., 'Nursing Sister Agnes Warner Was Entertained', Saint John Standard (5 April 1919); Anon., 'Returned Nursing Sister Entertained at Luncheon', Saint John Standard (8 April 1919).

123 Anon., 'Nursing Sister Agnes Warner Highly Honoured', Daily Telegraph (5 April 1919): 5.

124 Anon., 'Miss Warner Speaks at Reception'.

125 Anon., 'War's Lessons Should Not Soon be Forgotten'. See also: Anon., 'Returned Nursing Sister Entertained at Luncheon'.

126 Anon., 'Obituary', Saint John Globe. See also: Anon., 'Death Notice', Saint John Globe (23 April 1926): 10; Anon., 'Agnes Warner Death Notice and Obituary', Telegraph Journal (24 April 1926).

127 Higonnet, Nurses at the Front; Higonnet, 'Authenticity and Art'; Freedman, 'Mary Borden's Forbidden Zone'.

128 Borden, Journey down a Blind Alley: 7. 